\title{
PENGARUH PENDEKATAN GOAL ORIENTATION TERHADAP PRESTASI BELAJAR SISWA PADA MATA PELAJARAN TIK KELAS VIII MTS NW JURANG JALER
}

\author{
Juarsih $^{1}$, Farida Fitriani ${ }^{2}$ \\ ${ }^{1,2}$ Fakultas Ilmu Pendidikan dan Psikologi Universitas Pendidikan Mandalika \\ Email: serumpuh@gmail.com
}

\begin{abstract}
Abstrak
Tujuan penelitian ini, untuk mengidentifikasi pengaruh pendekatan goal orientation terhadap prestasi belajar siswa pada mata pelajaran TIK. Metode penelitian ini menggunakan eksperimen dengan pendekatan kuantitatif. Teknik pengumpulan data yang digunakan yaitu observasi, tes dan dokumentasi. Subjek penelitian ini siswa kelas VIII yang berjumlah 17 orang. Adapun hasil dari analisis penelitian ini diperoleh t hitung sebesar 8,652 sedangkan nilai. Sedangkan nilai t-tabel dengan taraf signifikan 5\% $\mathrm{dk}=1,761$ kenyataan ini menunjukkan bahwa nilai t-hitung yang diperoleh dalam penelitian adalah lebih besar daripada nilai t-tabel 8,652 > 1,761 yang berarti signifikan, maka dapat ditarik kesimpulan bahwa terdapat pengaruh pada pendekatan goal orientation terhadap prestasi belajar siswa kelas VIII MTs NW Jurang Jaler.
\end{abstract}

Kata Kunci: Goal Orientation, Prestasi Belajar, TIK

\section{PENDAHULUAN}

Teknologi Pendidikan merupakan suatu cara yang sistematis dalam mendesain, melaksanakan, dan mengevaluasi proses keseluruhan dari belajar dan pebelajaran dalam bentuk tujuan pembelajaran yang spesifik. Teknologi pendidikan menurut Nasution (2011) adalah suatu pendekatan yang sistematis dan kritis tentang pendidikan. Sedangkan menurut Abdullah (2010) mengatakan bahwa pendekatan sistematis dalam perencanaan, melaksanakan, dan mengevaluasi proses pembelajaran. Teknologi sengaja diciptakan untuk pendidikan, dengan adanya teknologi dalam pendidikan maka rancangan pendidikan akan terporgram sehingga proses pendidikan dapat teratur terperinci (Prawiradilaga 2012). Untuk membuat pelajaran lebih efektif dan menarik guru dituntut untuk membuat model atau pendekatan pembelajaran seperti goal orientation. Pada dasarnya pendekatan adalah suatu siasat yang digunakan oleh guru untuk menyampaikan materi kepada peserta didik dengan tujuan agar materi yang disampaikan mudah diterima dan mudah dipahami oleh peserta didik. Dengan pendekatan goal orientation siswa diharapkan mampu memahami materi pelajaran, termotivasi, dan menambah minat belajar siswa. Goal orientation adalah kesatuan perilaku yang menentukan pendekatan dan usaha siswa dalam melakukan kegiatan belajar. Goal orientasi dibedakan menjadi masteryorientation (orientation pada tugas) dan performance orientation ( orientasi yang mengacu pada harapan untuk mendapatkan reward) (Puspitasari, 2013). Goal orientation memiliki tujuan dan fokus keterlibatan seseorang dalam aktivitas berprestasi, sedangkan goal setting (penetapan tujuan) lebih berfokus pada bagaimana tujuan dibangun dan diubah secara peran sifatsifat tujuan itu untuk mendesak dan mengarahkan perilaku. Kadang tujuan digunakan sebagai istlah singkatan untuk goal orientation yang berbeda dari tujuan dalam teori goal setting (Schunk et al., 2010). Dalam penelitian ini fokus ke faktor kognitif yang dimiliki siswa yang menggambarkan integrasi pola belief yang dimiliki sehingga dapat membedakan pendekatan belajar yang mereka pakai, cara menggunakan, yang mengarah pada berbagai cara dalam merespon situasi berprestasi.

Berdasarkan hasil observasi prestasi belajar sisa pada mata pelajaran TIK sangat rendah, ini disebabkan oleh beberapa faktor yaitu guru kurang memperhatikan kebutuhan siswa, sehingga minat belajar siswa dalam proses pembelajaran juga rendah. 
Berdasarkan permasalahan tersebut penulis tertarik untuk meneliti terkait pengaruh presentasi belajar siswa dengan menggunakan pendekatan goal orientation.

\section{METODE PENELITIAN}

Metode penelitian ini menggunakan eksperimen. Metode eksperimen adalah metode penelitian yang digunakan untuk mencari pengaruh perilaku tertentu terhadap yang lain dalam kondisi terkendali (Sugiyono, 2013). Rancangan penelitian merupakan suatu langkah yang penting. Selanjutnya, apabila suatu itu dapat diukur dengan angka, maka disebut penelitian kuantitatif sesuai dengan namanya banyak ditentukan dengan menggunakan angka, mulai dengan pengumpulan data, penafsiran terhadap data tersebut serta penampilan dari hasilnya. Dalam penelitian ini, metode penelitian yang digunakan adalah metode kuantitatif yang disebut dengan (one creap) dikareakan data yang ingin dikumpulkan dan diproses adalah data yang berbentuk angka dan menggunakan statistic, rancangan penelitian ini mengikuti prosedur penelitian eksperimen yeng bertujuan untuk mengetahui pengaruh pendekatan goal orientation terhadap prestasi belajar siswa pada mata pelajaran TIK kelas VIII MTs NW Jurang Jaler. Adapun rancangan penelitian ini mengguanakan desain pre tes dan post tes group. Populasi adalah wilayah generasi yang terdiri dari objek atau sibjek yang menjadi kuantitas dan karakteristik tertentu yang ditetapkan oleh peneliti untuk dipelajari dan kemudian ditarik kesimpulannya (sugiyono, 2010). Menurut Arikunto (2013) mengatakan populasi adalah keseluruhan dari subjek penelitian. Populasi merupakan sumber data yang penting, karena tanpa kehadiran populasi penelitian tidak akan berarti serta tidak mungkin terlaksana. Berdasarkan pendapat para ahli dapat disimpulkan populasi adalah sekumpulan individu yang dikenakan perlakukan dalam penelitian. Jadi, populasi dalam penelitian ini adalahs iswa kelas VIII MTs NW Jurang Jaler. Sampel penelitian ini berjumlah 17 orang. Teknik pengumpulan data merupakan cara yang ditempuh untuk mendapatkan data yang konkret dari suatu objek yang diteliti (Maryadi dkk, 2010). Teknik pengumpulan data dalam penelitian menggunakan tes sebagai metode utama, dokumentasi dan observasi sebagai metode pelengkap. Menurut Arikunto (2016) tes merupakan alat atau prosedur yang digunakan untuk mengetahui atau mengukut suatu dalam suasana, dengan cara dan aturan-aturan yang sudah ditentukan. Tes adalah cara (yang dapat dipergunakan) atau prosedur (yang perlu ditempuh) dalam rangka pengukuran dan penilaian dibidang Pendidikan, yang berbentuk pemberian tugas atau serangkaian tugas baik berupa pertanyaan-pertanyaan yang harus dijawab. Dokumentasi yaitu mencari data mengenai hal-hal atau variable yang berupa catatan, tanskrip, buku, surat kabar, majalah, prasasti, notulen rapat, agenda dan sebagainya . dibandingkan dengan metode lain, maka metode ini tidak begitu sulit, dalam arti ada kekeliruan sumber data yang masih tetap belum berubah. Teknik observasi sering juga disebut dengan pengamatan dengan meliputi kegiatan pemuatan perhatian terhadap suatu objek dengan menggunakan seluruh alat indra (Arikunto, 2016).

Teknik analisis data menurut Miles dan Huberrman (2014) menyebutkan bahwa Teknik analisis data dalam penelitian kualitatif meliputi, pengumpulan data, reduksi data, penyajian data, penarikan kesimpulan. Data yang diperoleh dalam penelitian ini adalah data-data yang bersifat kuantitatif yang berupa angka-angka. Kemudian Langkahlangkah pelaksanaan metode analisis statistic sebagai cara untuk mengolah data atau untuk memperoleh hasil sesuai dengan yang diharapkan. Dalam penelitian ini metode analisis yang gunakan adalah analisis statistic t-tes. 


$$
t=\frac{M d}{\sqrt{\frac{\sum X^{2} d}{N(N-1)}}}
$$

Keterrangan

Md : Mean dari deviasi (diantara post-tes dan pre-tes)

$\sum \mathrm{d} \quad$ : Perbedaan deviasi dengan mean deviasi

$\mathrm{N} \quad$ : banyak subjek

dk : adalah N-1 (Suharsimi, 2010)

Adapun Langkah-langkah analisis statistic dalam penelitian ini adalah sebagai berikut: (1) merumuskan hipotesis (Ho), (2) Membuat table kerja, (3) Menguji nilai ttes, (4) Menarik kesimpulan.

\section{HASIL DAN PEMBAHASAN}

Adapun Langkah-langkah yang ditempuh dalam analisis data yaitu: (1) memasukkan hipotesis Nol (Ho). (2) Menyusun table kerja, (3) Memasukan data kedalam rumus, (4) menguji nilai, (5) menarik kesimpulan. Pada Langkah pertama merumuskan hipotesis (Ho) pada bab 1 telah dirumuskan hipotesis alternatif (Ha) yang diajukan dalam penelitian ini berbunyi: Ada pengaruh pendekatan Goal Orientation terhadap prestasi belajar siswa pada mata pelajaran TIK kelas VII di MTS NW Jurang Jaler. Selain hipotesis alternatif (Ha) yang telah diajukan dalam penelitian sebelumnya, maka analisis data diubah menjadi hipotesis nol (Ho), sehingga berbunyi tidak ada pengaruh pendekatan pendekatan goal orientation terhadap prestasi belajar siswa pada mata pelajaran TIK kelas VIII MTs NW Jurang Jaler. Antara hipotesis alternatif (Ha) dengan hipotesis nol (Ho) yang telah dirumuskan di atas terhadap hubungan yang berlawanan atau bertolak belakang dalam arti bila dalam penelitian ini hasil analisis data menunjukkan hipotesis nol (Ho) ditolak, maka berarti hipotesis alternatif (Ha) diterima. Demikian sebaliknya, dari hasil perhitungan ternyata nilai t-tes yang diperoleh dalam penelitian ini adalah 8,652 sedangkan nilai t-tabel dengan taraf signifikan 5\% dengan dk $=14$ adalah 1,761 kenyataan ini menunjukkan bahwa nilai t-tes yang diperoleh dalam penelitian ini adalah lebih besar dari pada nilai t-tabel. Dengan demikian pengujian $t$ tes di atas, dimana t-tes 8,652 lebih besar dari t-tabel sebesar 1,761 dengan taraf signifikan $5 \%$ maka dapat dikemukakan bahwa hipotesis nol (Ho) ditolak dan hipotesis alternatif (Ha) diterima. Jadi, dapat disimpulkan bahwa terdapat pengaruh pendekatan goal orientation terhadap prestasi belajar siswa pada mata pelajaran TIK siswa kelas VIII MTS NW Jurang Jaler.

\section{KESIMPULAN}

Dari hasil analisis data tersebut dapat disimpulkan bahwa t hitung yang diperoleh sebesar 8,652 sedangkan nilai t table dengan taraf signifikan $5 \% \mathrm{dk}=1,761$ kenyataan ini menunjukkan bahwa nilai $\mathrm{t}$ hitung yang diperoleh dalam penelitian adalah lebih besar daripada nilai t-tabel 8,652>1,761 berarti signifikan, maka kesimpulannya dalam penelitian ini adalah. Terdapat pengaruh pendekatan goal orientation terhadap prestasi belajari siswa kelas VIII di MTS NW Jurang Jaler. Hasil penelitian ini dapat memberikan masukan dan informasi kepada kepala sekolah dan guru TIK MTS NW Jurang Jaler. 


\section{DAFTAR PUSTAKA}

Arikunto, Suharsimi. 2016. Dasar-Dasar Evaluasi Pendidikan. Jakarta: PT. Bumi Aksara.

Djamrah, Syaiful Bahri. 2016. Psikologi Belajar. Jakarta: Rineka Cipta.

Komalasari, Kokom. 2013. Pembelajaran Kontekstual: konsep dan Aflikasi. Bandung: Refika Adiantara.

Maleong, L.J. 2011. Metodologi Pendidikan Kualitatif edisi refisi. Badung: Remaja Rosda Karya.

Muhibbin, Syah. 2013. Psikologi, dengan Pendekatan Baru. Bandung: Remaja Rosda Karya.

Nasution. 2011. Metode research penelitian ilmiah. Jakarta: Bumi Aksara.

Prawiradilaga, D.S. 2012. Wawasan Teknologi Pendidikan. Kencana Prenada MediaGrup

Poerwadarminta, W.J.S. 2010. Kamus Umum Bahasa Indonesia. Jakarta: Balai Pusaka.

Puspitasari, Elfayang R. A. 2013. Analisis Efektifitas, Efesiensi dan kontribusi Pajakan dan Retribusi daerah Kabupaten Blora. Skripsi Semarang: Universitas Diponogoro.

Rusman. 2012. Model-Model Pembelajaran. Depok: Raja Frafindo Persada.

Santrock, J.W., 2013. Psikologi Pendidikan. Edisi kedua. Jakarta: Kencana Prenada Media Grup

Suprijono, A. 2012. Cooperative learning. Yogyakarta: Pustaka Pelajar

Sugiyono. 2013. Metode Penelitian Pendidikan, Pendekatan Kuantitatif, Kualitatif, dan R \& D Bandung: Alfabeta. 